\title{
LAND USE CONFLICT AMONG VEGETABLE FARMERS IN DENU: DETERMINANTS, CAUSES AND CONSEQUENCES
}

\author{
Acquah Joyce De-Graft, Research Fellow \\ Department of Peace Studies, University of Cape Coast, Cape Coast, Ghana \\ E-mail: joycedaftacquah@gmail.com
}

\begin{abstract}
The study applies descriptive statistics and logistic regression analysis to investigate the causes, consequence and the determinants of land use conflict among vegetable farmers in Denu. Findings from the study indicate that multiple claims to ownership, land seen as the only source of survival, low level of education, strong population growth, legislative loopholes, and lack of access to land administration, erosion and inaccurate surveying were identified as the major causes of land use conflict among vegetable farmers in Denu. It further was revealed that land use conflicts increase cost, lead to loss of property, social and political instability, impact negatively on livelihoods and culminate in poor yield of crops and animals. The logistic regression result further revealed that length of years respondents have farmed on their plot, household size, years of education and income of respondents from other sources determine whether respondents experienced conflict or not. The study recommends that farmers engage in other businesses to reduce conflict. In addition, existing conflict resolution systems must be strengthened.
\end{abstract}

\section{KEY WORDS}

Causes, consequences, determinants, land use conflict, vegetable farmers, logistic regression, Denu.

In Ghana, as in other Sub-Saharan African countries, contestation over land is particularly acute, and seems likely to intensify over time. This is as a result of the pressures of population growth, cash-crop led agriculture, large scale migration, and rapid urbanization which have produced increased conflicts over land (Crook, 2005; Yelsang, 2013). It has been shown that local land conflicts can erupt into large-scale civil strife and political movements (Fred-Mensah, 1999; Daudelin, 2002; Yamano \& Deininge, 2005).

Despite the increasing incidences of land use conflicts, previous studies on this topic have been limited to some specific incidences related to large-scale civil strife or politically motivated conflicts. Studies on land use conflict undertaken in Ghana and other countries to the best of our knowledge have not assessed the causes and consequences of land use conflict. Specifically the vegetable farmers in Denu do experience land use conflict, however much work have not been done to investigate the causes, consequence and determinates of these land use conflicts. This paper intends to fill the gap in the literature. Therefore the objective of this paper is to examine the determinants of land use conflicts, assess the causes and consequences of such conflicts among vegetable farmers in Denu. Descriptive statistics was used in assessing the causes and consequences of land use conflict and the determinants of land use conflicts was estimated using logistic regression model. The paper is structured as follows. The introduction is followed by the review of related literature on land use conflict. This is followed by the materials and methods which presents the logistic regression model followed by the discussion of results. Finally the paper ends with conclusions and recommendations.

\section{LITERATURE REVIEW}

Land is a fundamental factor in agricultural production. It plays an essential role in increasing as well as sustaining agricultural production. The extent to which this role is performed is determined in part by methods of land acquisition and arrangements for the 
ownership and use of land. Rights in rural land can be acquired or transferred through inheritance, gift, purchase, loan, pledge and allocation (by family head, local chief or any land custodian) (Alawode, 2013). However, inheritance is the most important and common way of acquiring land in Ghana (Fred-Mensah, 1999).

Land provides a major source of conflict in rural societies around the world (Cotula, Toulmin, \& Hesse, 2004). Feuds between families, neighbours and adjourning communities frequently can be traced back to conflicting claims over inheritance, boundaries and rights. All societies have evolved mechanisms for resolving disputes, with varying sanctions, levels of force, processes involved and principles to guide decision-making. Cotula et al. (2004) argue further that, in sub-Saharan Africa, competition over land has increased in frequency and severity in the last decades. The reasons for this are multiple, and essentially linked to the increased scarcity of land caused by demographic pressures and to the higher land values determined by agricultural intensification and commercialisation

Conflict is a state of clashing or opposing interests. It occurs when two or more people oppose one another because of differences in their needs, wants, goals or values (Upreti, 2001). Conflict is an indicator of a changing society. Rapid changes due to new technologies, commercialization of common property resources, privatization of public services, growing consumerism, and government policies, are all contributing to emergence of conflict (De Zeeuw, 1997; Upreti, 2002). Platteau (2000) explained that when land acquires a scarcity value, landholders begin to feel uncertain about the strength of their customary rights, and disputes over ownership of land, inheritance and land boundaries tend to multiply. Landholders tend to assert increasingly individualized use rights to given plots as population continues to rise, such as the right to resume cultivation of a specific plot after a period of fallow; the right to assign the plot to a heir or to a tenant; the right to prevent secondary claimants (for example, the right of pastoral herders to graze their animals on crop stubbles) from exercising their traditional prerogatives; and the right to dispose freely of the land. This increasing assertion of individualized rights gives rise to numerous conflicts which become more difficult to resolve and entail rising costs (Alawode, 2013).

Deininger and Castagini (2006) explained that conflicts in many parts of the developing world can be traced to disputes over land ownership and land use. Idowu (2002) explained that conflicts arise among land resources users due to lack of standards, inadequate legislation, and non enforcement of legal (and customary) provisions where they exist as well as ignorance and/or disregard for other land users. Similarly, myopic planning of development projects that utilize agricultural and grazing lands may lead to conflicts among the major players in land resources use (Idowu, Alawode, Alimi, \& Kassali, 2008; Alawode, 2013). Also, Idowu (2002) found that the root cause of all communal conflicts in the Guinea Savannah Zone of Nigeria can be traced to the problem of types and the control of such resources. Furthermore, Yamano and Deininger (2005) explained that death of household head (males and female for female-headed households) and household size determines the level of land use conflict in Kenya.

\section{MATERIALS AND METHODS OF RESEARCH}

Denu is a medium-sized town in the Volta region of Ghana, situated near the coast, three miles from the border with Togo and around 116 miles east of the capital Accra. Denu is the capital of Ketu South Municipal. The estimated population is 117,000 . The main source of employment in the area is fishing and vegetable farming.

The sample for the study comprises 102 vegetable farmers in Denu. The population for the study was all vegetable farmers in Denu. Multistage random sampling technique was used to select respondents of the study. The first stage involved random sampling of six different vegetable farmers (namely; onion, tomatoes, pepper, carrot, cucumber, cabbage). Seventeen (17) respondents were selected from each of the vegetable farmer groups.

An interview schedule was the main tool of data collection while descriptive statistics and logistic regression analysis were the main analytical techniques. The basic model of the logit estimation is as follows: 


$$
\mathrm{P}_{i}=\operatorname{Pr} o b\left(Y_{i}=1\right)=\frac{1}{1+e^{-\left(\beta_{o}+\beta_{1} X_{1 i}+\ldots \ldots . \beta_{k} X_{k i}\right)}}=\frac{e^{\left(\beta_{o}+\beta_{1} X_{1 i}+\ldots \ldots . \beta_{k} X_{k i}\right)}}{1+e^{-\left(\beta_{o}+\beta_{1} X_{1 i}+\ldots \ldots . \beta_{k} X_{k i}\right)}}
$$

Similarly,

$$
\mathbf{P}_{i}=\operatorname{Pr} o b\left(Y_{i}=0\right)=1-\operatorname{Pr} o b\left(Y_{i}=1\right)=\frac{1}{1+e^{\left(\beta_{0}+\beta_{1} X_{1 i}+\ldots \ldots \beta_{k} X_{k i}\right)}}
$$

Dividing (1) by (2) we get:

$$
\frac{\operatorname{Pr} o b\left(Y_{i}=1\right)}{\operatorname{Pr} o b\left(Y_{i}=0\right)}=\frac{P_{i}}{1-P_{i}}=e^{\left(\beta_{o}+\beta_{1} X_{1 i}+\ldots \ldots . \beta_{k} X_{k i}\right)}
$$

Where $P_{i}$ is the probability that $Y$ takes the value 1 and then $\left(1-P_{i}\right)$ is the probability that $Y$ is 0 and e the exponential constant.

Data were analysed using STATA version 13.0. Results of the study were presented in tables and bar charts while frequencies and percentages were used to discuss the results

\section{RESULTS AND DISCUSSION}

Socio-economic Characteristics of Respondents. In this section the findings on the socioeconomic characteristics of the survey respondents are reported. The sample tended to be older with 77 percent of the respondents above the age of 42 years with 23 percent below 42 years. With respect to gender, 66 percent of respondents were males whereas 34 percent were females. Majority (55 percent) of the respondents were married. In terms of education, 34 percent and 12 percent had primary education and secondary school education respectively while 25 percent had no formal education, 13 percent had tertiary and 15 percent had technical/vocational education respectively. With respect to household size, household size 10 and above are about 10 percent. Of the 102 respondents interviewed 45 percent of respondents had household size ranging from 4 to 6 . Also about 30 and 15 percent of respondents had household size ranging from 1 to 3 and 7 to 9 respectively. It was found that 53 percent of respondents have lived on their farms for 25 years and above.

The monthly income of respondents both from farming and from other sources is presented. It was realized that, about 47 percent receive monthly income above $\mathrm{GH} \phi 400$ from farming, 14 percent receive between the amounts of $\mathrm{GH} \phi 200-299$ and $\mathrm{GH} \phi 300-399$ monthly, 13 percent receive between the amounts of $\mathrm{GH} \phi 00-99$ and 12 percent receive between the amount of $\mathrm{GH} \phi 100-199$. With respect to monthly income earned from other sources other than farming, we realized that 33 percent receive a monthly income between the amount of $\mathrm{GH} \phi 00-99,29$ percent receive a monthly income of $\mathrm{GH} \phi 400$ and above, 19 percent receive a monthly income between the amount of $\mathrm{GH} \phi 200-299$ and about 5 percent receive a monthly income between the amount of $\mathrm{GH} \phi 300-399$.

Analysis of levels of Land Use Conflicts. From the analysis of the responses from the farmers, the levels of land use conflicts identified in the study area are presented in Table 1. Experienced conflict before: respondents were asked if they have ever experienced conflict on their plot before. Past conflict resolved: respondents experienced conflict on the plot in the past but has been resolved, whether informally through the village elders, the farmers' groups, village heads, family heads or formally through the police/courts. Currently experiencing conflict: respondents were asked if they are currently experiencing conflict. Anticipate future conflict: respondents were asked if they anticipate future conflict on their plot of land.

Results show that more than half of the respondents (55 percent) have experienced conflicts before but 59 percent of respondents agreed that the conflicts had been resolved. 
As to whether the respondents were currently experiencing conflicts, about 82 percent indicated that they are not. In the same vein about 70 percent of respondents did not anticipate any future conflict on their plot of vegetable farm land.

Table 1 - Levels of Land Use Conflict

\begin{tabular}{ccc}
\hline Level of Conflict & $\begin{array}{c}\text { Percent answering } \\
\text { Yes (frequency) }\end{array}$ & $\begin{array}{c}\text { Percent answering } \\
\text { No (frequency) }\end{array}$ \\
\hline Experienced conflict before & $55.24(56)$ & $44.76(46)$ \\
Past conflict resolved & $59.05(60)$ & $40.95(42)$ \\
Currently experiencing conflict & $18.10(18)$ & $81.9(84)$ \\
Anticipate future conflict & $30.48(31)$ & $69.52(71)$ \\
\hline
\end{tabular}

Source: Survey Data, 2014.

Determinants of Land Use Conflicts among Vegetable Farmers in Denu. The normal regression models that can be used in the case of analysis of variables such as production or consumption which is an interval variable, in which each unit of measurement carries equal weight, are inappropriate when modelling involves the use of qualitative response for the dependent variable. When there is a single decision there are only two possible outcomes; the logistic model is used. The logistic regression model is appropriate in this analysis because of the binary qualitative responses of the dependent variable. The dependent variable is conflict on the plots covered by the study; whether the plot owner experienced conflict on that plot, or not at the time of this study.

Model specification. Following Yamano and Deininger (2005) and Alawode (2013), the dependent variable is conflict measured as $1=$ if households experienced conflicts on their plots and $0=$ otherwise. Therefore the model for our data is specified as:

$$
\text { conflict }_{i}=\beta_{0}+\beta_{1} \text { age }_{i}+\beta_{2} \text { hsize }_{i}+\beta_{3} \text { inc }_{i}+\beta_{4} y_{-} \text {edu } u_{i}+\beta_{5} \text { dist }_{i}+\beta_{6} \text { output }_{i}+\beta_{7} \text { length }_{i}+\varepsilon_{i}
$$

\section{Where:}

age $=$ Age of respondent measured in years;

hsize $=$ Number of people in respondents' household;

inc $=$ Income of respondents from other sources other than farming in Ghф;

y_edu = Years of formal education of respondents;

dist = Distance from respondents house to their farms in $\mathrm{km}$;

output $=$ Total output of respondents farm yield in $\mathrm{kg}$;

length $=$ Number of years respondents have farmed on their plot of land.

The Maximum Likelihood Estimation (MLE) technique was used to estimate the logit model. From the results, the Wald chi square value of 25.32 with 7 degrees of freedom and a p-value of 0.000 less than 0.05 shows that the model has a good fit for the data. Besides, the Hosmer-Lemeshow model fitness test shows that we cannot reject our model which also means our model fits reasonably well. The link test also reveals no problems with the specification of our model. The results in Table 2 show the estimated coefficients of the variables for whether respondents experienced conflict or not. Only four explanatory variables were found to be significant. These variables are therefore interpreted and explained as indicated in Table 2. An increase in the household size of respondents by one person increases the probability of the respondents experiencing conflict on their farm plot by $5.1 \%$ at 10 percent significant level holding other variables constant. This finding is consistent with Yamano and Deininger (2005). With respect to income of respondents from other sources: $\mathrm{GH} \phi 1$ increase in the income of respondents from sources other than farming decreases the probability of the respondents experiencing conflict on their farm plot by $5.3 \%$ at 5 percent significant level holding other variables constant. An additional year of formal education of respondents reduces the probability of the respondents experiencing conflict on their farm plot by $2.1 \%$ at 10 percent significant level holding other variables 
constant. An additional year farmed on plot increases the probability of the respondents experiencing conflict on their farm. This finding is consistent with results by Alawode (2013).

Table 2 - Determinants of land use conflicts among vegetable farmers in Denu

\begin{tabular}{|c|c|c|}
\hline Dependent Variable: Conflict & & \\
\hline Explanatory Variables & Coefficients & Marginal Effects \\
\hline Age & $\begin{array}{l}0.025 \\
(1.19)\end{array}$ & -0.004 \\
\hline Household size & $\begin{array}{l}0.285^{*} \\
(1.67)\end{array}$ & 0.051 \\
\hline Income of farmer from other sources & $\begin{array}{c}-0.295^{\star *} \\
(-2.12)\end{array}$ & -0.053 \\
\hline Years of education & $\begin{array}{c}-0.119 \\
(-1.68)^{*}\end{array}$ & -0.021 \\
\hline Distance from home to farm & $\begin{array}{l}-0.004 \\
(-0.17)\end{array}$ & -0.000 \\
\hline Total output $(\mathrm{kg})$ of farm yield & $\begin{array}{l}-0.041 \\
(-1.25)\end{array}$ & -0.007 \\
\hline Length of years farmed on plot & $\begin{array}{c}0.002^{\star *} \\
(2.02)\end{array}$ & 0.000 \\
\hline Constant & $\begin{array}{l}-1.715 \\
(-1.32)\end{array}$ & \\
\hline Link test for specification & & \\
\hline & $\begin{array}{c}0.941^{\star * \star} \\
(4.18)\end{array}$ & \\
\hline _hatsq & $\begin{array}{l}.0194 \\
(1.09)\end{array}$ & \\
\hline$N$ & 105 & \\
\hline Wald chi2(7)(p-value) & $25.32(0.000)$ & \\
\hline Hosmer-Lemershaw test for goodness-of-fit ( $\mathrm{P}$-value) & $97.84(0.457)$ & \\
\hline
\end{tabular}

$t$ statistics in parentheses.

${ }^{*} p<0.1,{ }^{* *} p<0.05,{ }^{* * *} p<0.01$.

Source: Survey data, 2014.

Causes of Land Use Conflict. This section explains the causes of land use conflicts among vegetable farmers in Denu. The causes are grouped according to political, economic and socio-cultural, demographic, legal and judicial, administrative, technical and ecological, and psychological. Each of the causes is explained in detail in the ensuing paragraphs. From Figure 1 below the political causes are presented. Most (84 percent) of the respondents agreed that multiple claims to ownership is the major political cause. 73 and 67 percent agreed that political support for big farmers to the disadvantage of poor peasants and change of family heads respectively are other political causes. It is worth noting that 68 percent of respondents indicated that change in political and economic system, incuding nationalization or privatization of land is not a major political cause of land use conflict as shown in figure 1. 


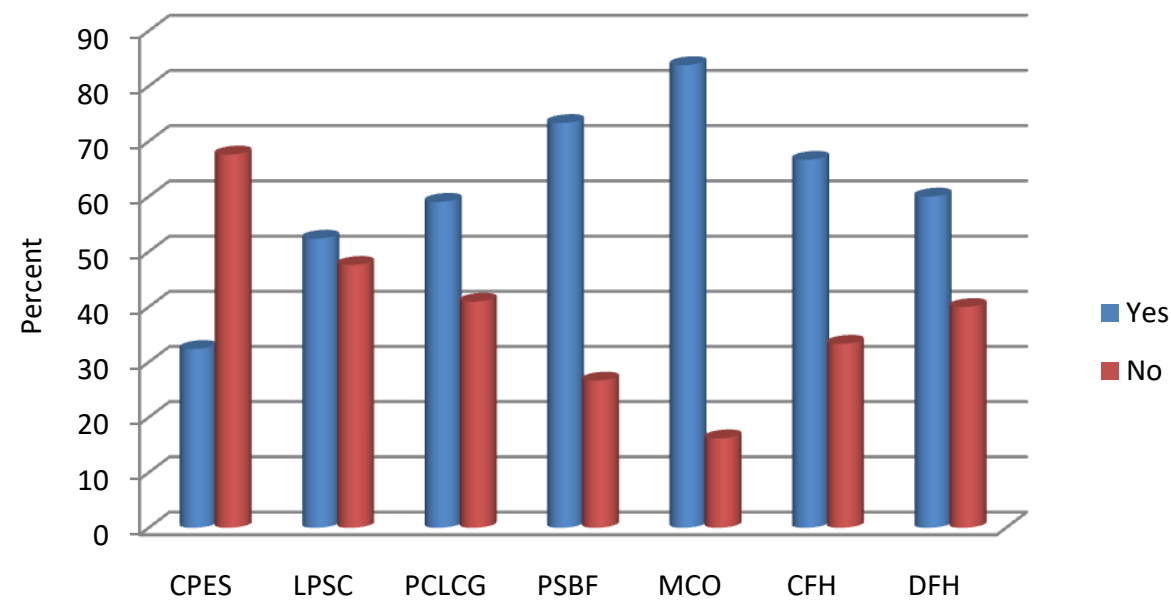

Political cuases of land use conflict

Note: $C P E S=$ Change in political and economic system,incuding nationalization or privatization of land, LPSC $=$ Lack of political stability and continuity, PCLCG = Political corruption, state capture and land grabing, PSBF = Political support for big farmers to the disadvantage of poor peasnats, $M C O=$ Multiple claims to ownership, $\mathrm{CFH}=$ change of family heads, $D F H=$ Death of family heads.

Figure 1 - Political causes of land use conflicts (Source: Survey Data, 2014)

With respect to economic causes of land use conflicts, 80 percent explained that they see land as the only source of survival. 79 percent explained that land sales to multiple owners and 75 percent indicated that desire of increasing personal wealth are economic causes of land use conflicts. 55 percent of respondents indicated that increasing land prices is a cause of land conflicts. These are shown in figure 2.

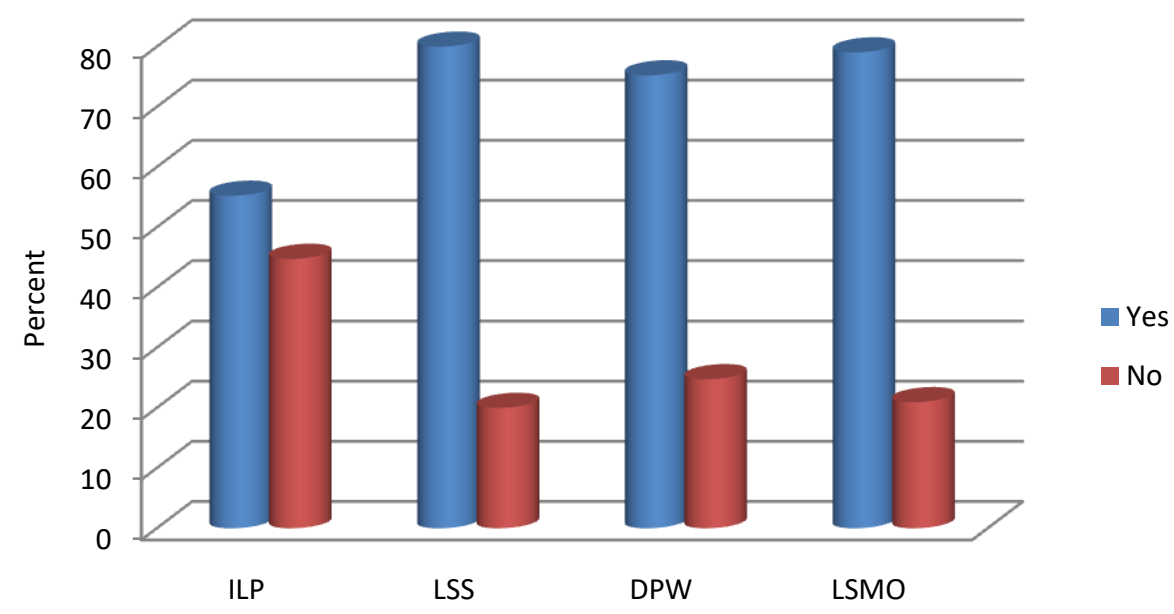

Economic causes of land use conflict

Note: ILP = Increasing land prices, $L S S=$ Land seen as the only source of survival, DPW $=$ Desire of increasing personal wealth, $L S M O=$ Land sales to multiple owners.

Figure 2 - Economic causes of land use conflicts (Source: Survey Data)

It can be seen from the Figure 3 below that 78 and 75 percent of respondents agree that low level of education and lack of information on institutions and mechanisms of land markets and unregistered land transactions are the major socio-economic and socio-cultural causes of land use conflict. Also 63, 60 and 61 percent of respondents agree that extreme unequal distribution of power and resources, deteriorated traditional values, structure and 
rejection of formal institutions are other socio-cultural causes of land use conflict respectively.

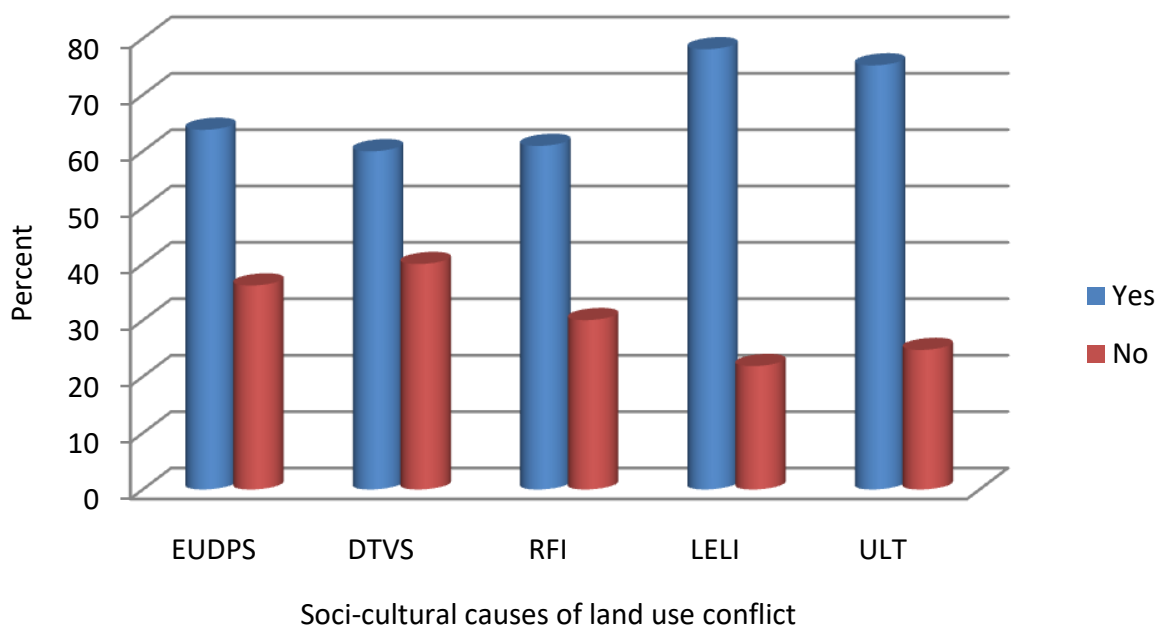

Note: EUDPS = Extreme unequal distribution of power and resources, DTVS = Deteriorated traditional values and structure, $R F I=$ Rejection of formal institutions, $L E L I=$ Low level of education and lack of information on institutions and mechanisms of land markets, ULT=Unregistered land transactions.

Figure 3 - Socio-cultural causes of land use conflicts (Source: Survey Data)

As shown in figure 4 below, with respect to demographic causes of land use conflicts, 71 percent of respondents explained that strong population growth is a major demographic cause of land use conflict while 54 percent explained that new and returning immigrants cause land use conflicts.

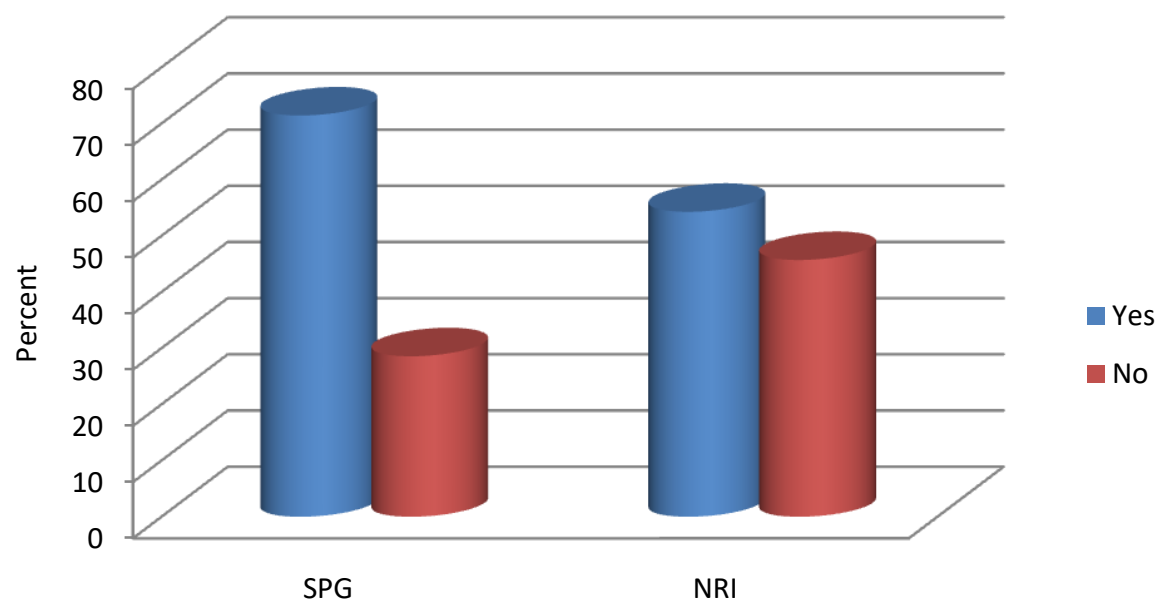

Demographic causes of land use conflict

Note: $S P G=$ Strong population growth, NRI = New and returning immigrants.

Figure 4 - Demographic causes of land use conflicts (Source: Survey Data, 2014)

Also, it can be seen from the Figure 5 that 70 percent of the respondents agree that missing or inactive mechanisms for sanctions is a major legal cause of land use conflict. Also 69 percent of respondents agree that legislative loopholes is a legal cause of land use conflict. As regards contradictory legislation as a legal cause of land use conflict about 65 
percent agreed while 60 percent agreed that traditional law without written records or clearly defined plot and village boudaries legally causes of land use conflict. These findings are in agreement with that of Idowu (2002) and Deininger and Castagnini (2006).

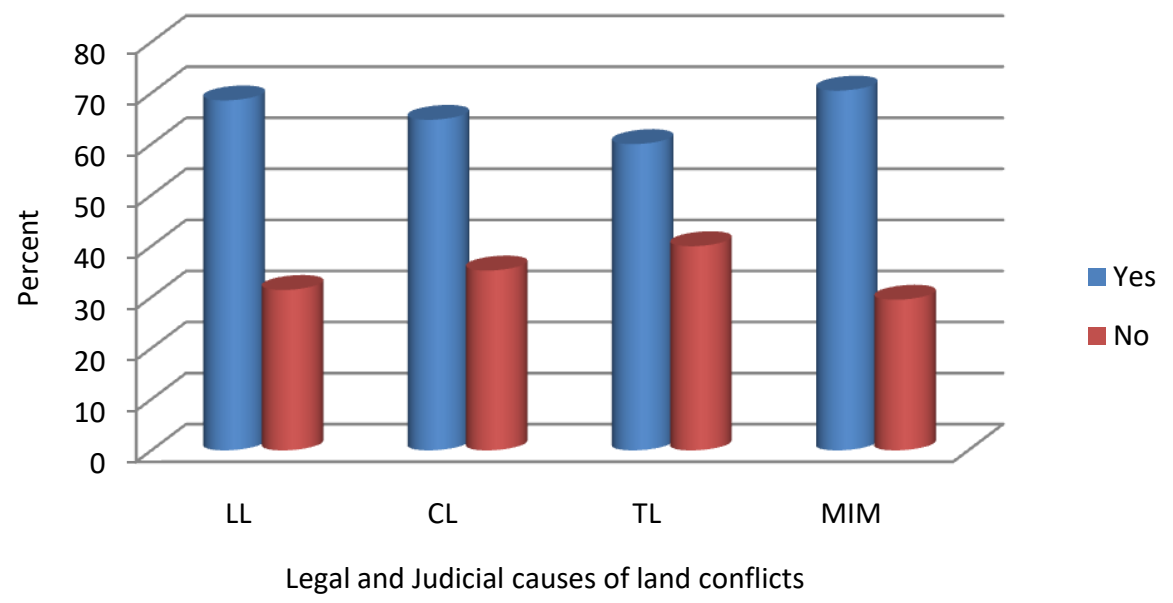

Note: $L L=$ Legislative loopholes, $C L=$ Contradictory legislation, $T L=$ Traditional law without written records or clearly defined plot and village boudaries, MIM = Missing or Inactive mechanisms for sanctions.

Figure 5 - Legal and Judicial causes of land conflicts Source: Survey Data

Furthermore, as illustrated in Figure 6 respondents interviewed agreed to all four administrative causes of land use conflict. It was realized that 79 percent of respondents alluded to the opinion that lack of access to land administration, especially for the poor and rural population leads to land use conflicts. While 70 percent agree that limited or nonexistence public participation, especcially in land use planning and demarcation of concession lands causes of land use conflict, 66 percent of respondents agree that lack of responsibility and accoountability leads to land use conflict with 63 percent indicating that lack of communication, co-operation and co-ordination within and between different government agencies as well as between public and private sector causes of land use conflict.

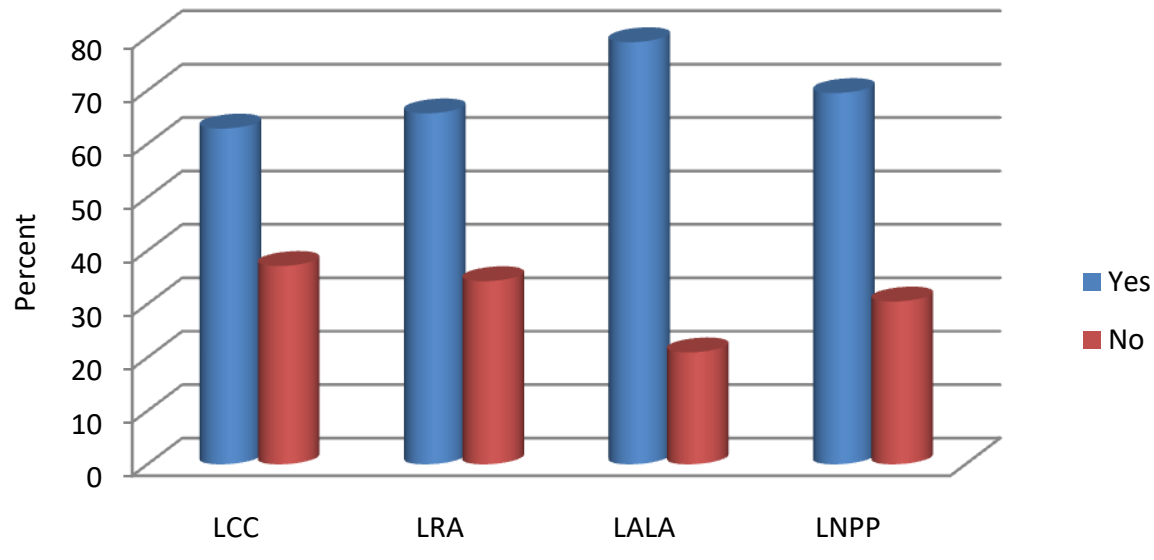

Administrative causes of land conflicts

Note: $L C C=$ Lack of communication, co-operation and co-ordination within and between different government agencies as well as between public and private sector, $L R A=$ lack of responsibility and accoountability, $L A L A=L a c k$ of access to land administration, especially for the poor and rural population, LNPP = Limited or non-existence public participation, especcially in land use planning and demarcation of concession lands.

Figure 6 - Administrative causes of land conflicts (Source: Survey Data) 
In addition, it can be seen from the Figure 7 that 76 percent of respondents are of the opinion that erosion, drought or floods leading to urban migration is a major ecological cause of land use conflict. With respect to technical cause of land use conflict, while 73 percent agree that missing or inaccurate surveying causes of land use conflict, about 68 percent of respondents agree that missing land register or one that does not meet modern requirment results in land use conflicts. However, about 52 percent indicated that missing housing programmes does not realy cause of land use conflicts.

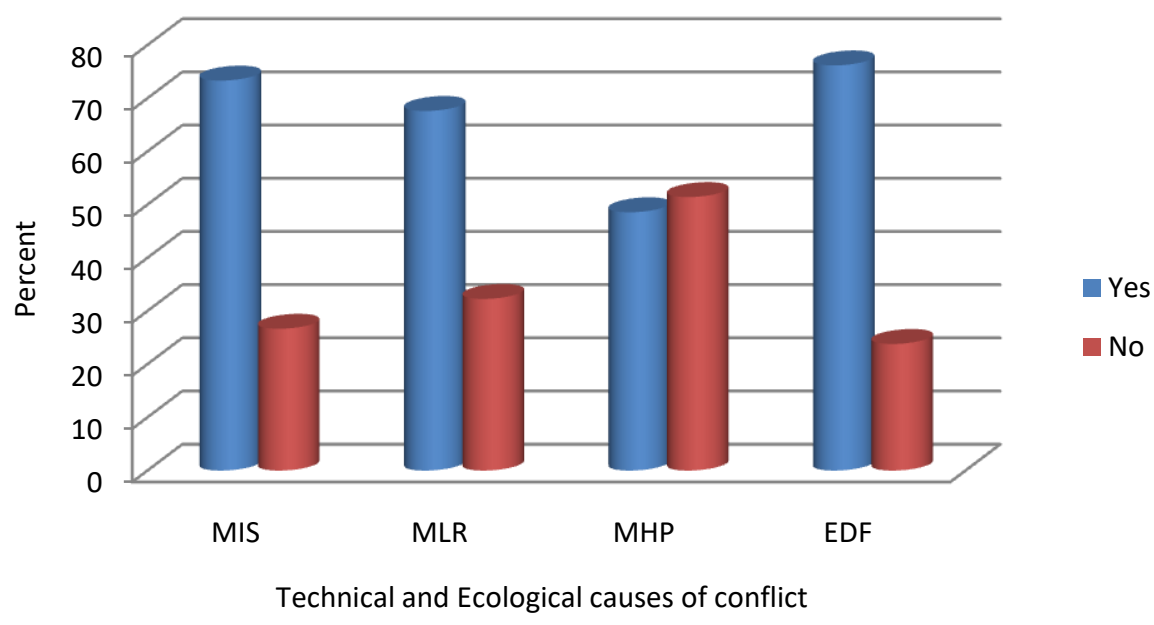

Note: $M I S=$ Missing or inaccurate surveying, $M L R=$ Missing land register or one that does not meet modern requirment, $M H P=$ Missing housing programmes, EDF = Erosion, drought or floods leading to urban migration.

Figure 7 - Technical and Ecological causes of land conflicts (Source: Survey Data)

Finally, as illustrated in Figure 8 about 60 percent of respondents interviewed do not agree fear for one's existence causes land use conflict. However, about 65 percent of respondents agree that thirst for power psychologically causes land use conflits with about 53 percent of respondents indicating that psychlogically, loss of one's identity leads to land use conflits.

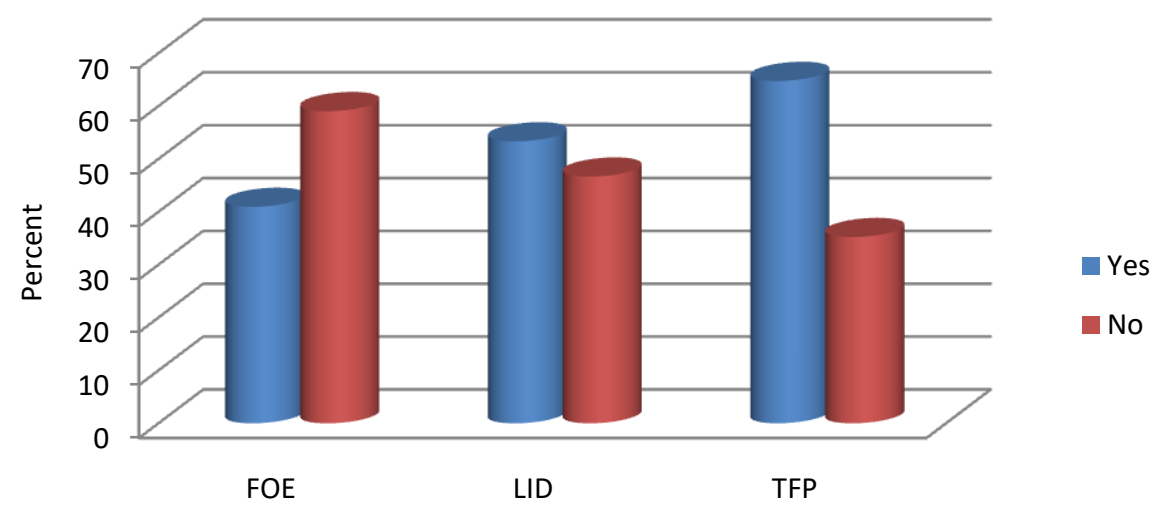

Psychological causes of land conflict

Note: FOE = Fear for one's existence, $L I D=$ Loss of identity, TFP = Thirst for power .

Figure 8 - Psychological causes of land conflicts (Source: Survey Data)

Consequences of Land Use Conflict. This section examines the consequences on land use conflicts. Figure 9 shows the consequences of land use conflicts. With respect to the 
consequence of conflicts on cost and investment and loss of property, most (83 percent) of the respondents agreed conflicts increase cost and slow down investment and loss of property. 78 and 87 percent agree that conflicts lead to social and political instability and impact negatively on livelihood.

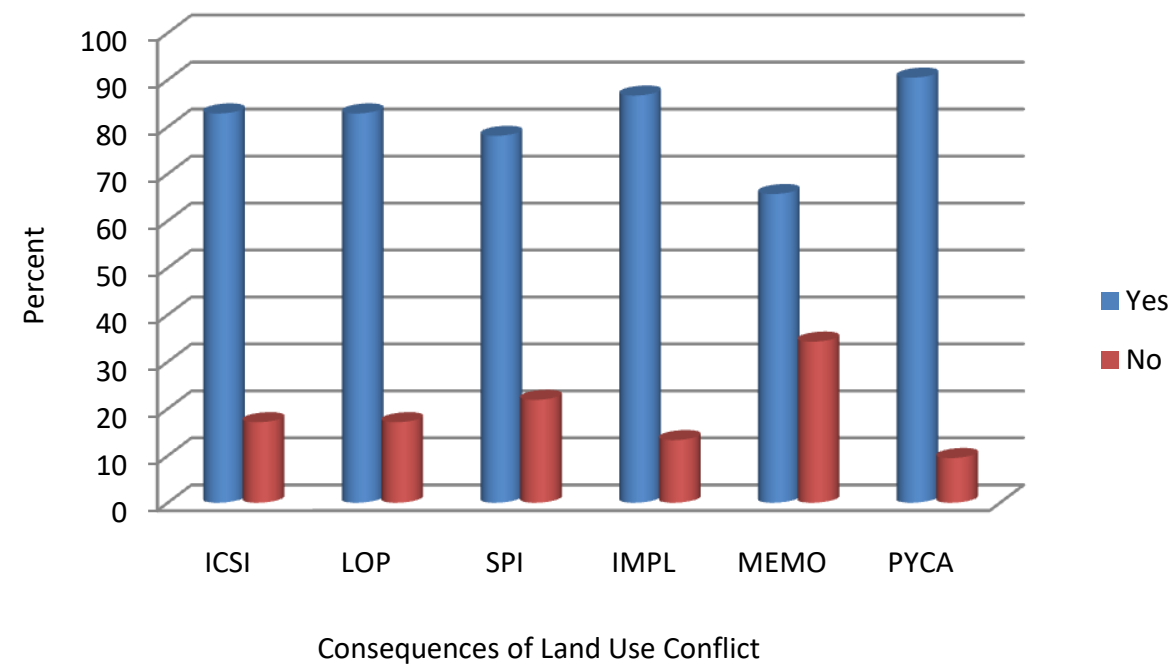

Note: $I C S I=$ Increase cost and slow down investment, $L O P=$ Loss of property, $S P I=$ Social and political instability, $I M P L=$ Impact on livelihoods $M E M O=$ Marginalization of ethnic minority and ophans, $P Y C A=$ Poor yield of crop and animal.

Figure 9 - Consequences of land use conflicts (Source: Survey Data, 2014)

Also 66 percent of respondents indicated that conflicts lead to ethnic minorities and ophans being extremely marginalized. 90 percent explained that conflicts result in poor yield of crop and animal. In sum, majority of respondents agree to the various consequences of conflicts.

\section{CONCLUSION AND RECOMMENDATIONS}

Land is crucial in agricultural production and that land use conflicts disrupt agricultural production in Ghana, this study has examine the determinants of land use conflicts; assessed the causes and consequences of land use conflicts among vegetable farmers in Denu using survey data of 102 farmers. The results indicate that the length of years respondents have farmed on their plot, household size, years of education and income of respondents from other sources determine whether farmers experienced land use conflict or not. With respect to the causes of land use conflict, multiple claims to ownership, land seen as the only source of survival, low level of education, strong population growth, legislative loopholes, lack of access to land administration, erosion and inaccurate surveying were identified as the major causes.

Regarding the consequences of the land use conflicts on the vegetable farmers in Denu, majority of respondent supported the view that land use conflicts increase cost and slow down investment, lead to loss of property, social and political instability, impact negatively on livelihoods and culminates in poor yield of crops and animals. The study recommends that policy makers should advise farmers to ensure that farmers engage in other businesses and continue their education to higher levels to reduce conflict since income of farmer from other sources and more years of education reduces the probability of experiencing conflicts. Also, the causes of land use conflicts must be tackled from political, economic, socio-cultural, demographic, legal and judicial, administrative, technical, ecological and psychological perspectives. In addition, existing conflict resolution systems must be strengthened to deal with land use conflict if they occur. 


\section{REFERENCES}

1. Alawode, O. O. (2013). Determinants of land use conflicts among farmers in southwestern Nigeria. Journal of Research in Peace, Gender and Development, 3(4), 58-67.

2. Cotula, L. Toulmin, C. \& Hesse, C. (2004). Land tenure and administration in Africa: lessons of experience and emerging issues. London, UK: International Institute for Environment and Development.

3. Crook, R. (2005). Access to justice and land disputes in Ghana's state courts: the litigants' perspective. Institute of Development Studies (Working Paper 241, Brighton).

4. Daudeline, J. (2002). Land as a source of conflict and in post-conflict settlement. World Bank Regional Workshop on Land Issues in Africa and the Middle East, April 29-May 2, 2002, Kampala, Uganda.University of Ibadan, Nigeria.

5. De Zeeuw, F. (1997). Borrowing of land, security of tenure and sustainable land use in Burkina Faso. Development and Change, 28(3), 583-595.

6. Deininger, K. and Castagnini, R. (2006), Incidence and impact of land conflict in Uganda. Journal of Economic Behavior \& Organization, 60(3), 321-345.

7. Fred-Mensah, B. K. (1999). Capturing ambiguities: communal conflict management alternative in Ghana. World Development, 27(6), 951-965.

8. Idowu, E. O. (2002). Land use conflict between crop and livestock producers in the Guinea Savannah Zone of Nigeria. Nigerian Journal of Animal Production, 29(2), 234-244.

9. Idowu, E. O., Alawode, O. O., Alimi, T., \& Kassali, R. (2008). Analysis of agricultural land market in Ondo State of Nigeria. Bowen Journal of Agriculture, 4(1), 76-93.

10. Plattaeu, J. P. (2000). Does Africa Need Land Reform? in Toulmin, C. and Quan, J. F. (Eds). Evolving Land Rights, Policy and Tenure in Africa, DFID/IIED/NRI, London, pp. $51-73$.

11. Upreti, B. R. (2001). Conflict Management in Natural Resources: A Study of Land, Water and Forest Conflict in Nepal [PhD Dissertation, Wageningen University]. https://edepot.wur.nl/139410

12. Upreti, B. R. (2002). Management of Social and Natural Resource Conflict in Nepal: Realities and Alternatives. New Delhi, India: Adroit Publishers.

13. Yamano, T., \& Deininger, K. (2005). Land conflicts in Kenya: causes, impacts, and resolutions. Foundation for Advanced Studies on International Development/National Graduate Institute for Policy Studies. The World Bank, 28.

14. Yelsang, F. D. (2013). Agricultural land use conflict between landlords and migrant farmers in Ghana: an examination of issues affecting dagara migrants in the Brong Ahafo region. European Scientific Journal, 9(29), 1-15. 